\title{
Is the activity of benthic suspension feeders a factor controlling water quality in the Bay of Brest?
}

\author{
Christian Hily
}

Laboratoire d'Océanographie Biologique, Université de Bretagne Occidentale, F-29287 Brest Cedex, France

\begin{abstract}
In the Bay of Brest, France, suspension feeders are broadly dominant in the trophic structure of macrobenthic assemblages in terms of species number, number of individuals and biomass. A succession of species exists on an east-west gradient, which is an ecological continuum from a $<10 \mathrm{~m}$ depth polyhaline muddy environment to a $>20 \mathrm{~m}$ depth marine environment with coarse and clean sediments. The abundance of biogenic substrates (shells, calcareous algae, etc.) on the sediment surface favours a high development of sessile epifauna. Some species, such as Crepicula fornicata, Ascidiella aspersa, Ficulina ficus, Ophiothrix fragilis and Ophiocomina nigra, can locally proliferate, reaching $100 \mathrm{~g}$ ODW (organic dry wt) $\mathrm{m}^{-2}$. Fertilization of the bay by streams loaded with nutrients induces a very high primary production $\left(280 \mathrm{~g} \mathrm{C} \mathrm{m}^{-2} \mathrm{yr}^{-1}\right)$ characterized by high annual and seasonal variability of phytoplanktonic blooms. However, so far, eutrophication has not been observed. While water renewal by tidal currents is one important factor in the control of eutrophication, suspension feeder activity is undoubtedly another effective control factor. Benthic suspension feeders can filter $7.18 \times 10^{8}$ $\mathrm{m}^{3}$ daily, which represents ca $30 \%$ of the total volume of the bay. The phytoplankton production is easily accessible to the benthos because of the relatively long water residence time and the high tidal current mixing. Spatial distribution of populations was found to be related to the tidal current distribution.
\end{abstract}

\section{INTRODUCTION}

Coastal marine ecosystems are regarded as playing an important role in the fields of marine resource, economic and aquacultural activities. Recent studies have focused on the natural functioning of these environments, and on perturbations induced by multiple anthropogenic stresses. The major factors controlling eutrophication were identified as: daylight, turbidity, temperature, and biogeochemical and planktonic cycles. In the last few years, the role of benthic organisms, especially suspension-feeding macrofauna, as a control factor of the phytoplankton biomass has been demonstrated. Smayda (1976) and Hobbie (1976) drew attention to these mechanisms, but only since 1980 have real experiments been conducted to quantify the role played by benthic grazing in the control of the overlying waters (Boynton et al. 1980, Dame et al. 1980); the dense suspension-feeder populations filtered a sufficient amount of water daily to consume a large part of the algal production in south San Francisco bay (Cloern 1982). The impact of filtration intensity on the environment is related to tidal mixing and the depth of the water column.
While seston retention is the primary active mechanism, biodeposition of faeces and pseudofaeces of suspension feeders on the sediment surface may also control other dynamic features of the ecosystems such as the flux of particles to the sediments. This mechanism is well documented in oyster culture (Sornin 1981, Heral et al. 1983), but natural suspension-feeder populations can also accelerate the flux of particles to the sediment: e.g. Crepidula fornicata Linnaeus in the Bay of Marennes-Oleron, France (Desloup-Paoli et al. 1983), and Cerastoderma edule Linnaeus in intertidal flats of the Oosterschelde estuary, Holland (Smaal et al. 1986). In a lagoonal area (Lake Grevelingen, Holland) De Vries et al. (unpubl.) estimated that biodeposition on the sediment surface by suspension-feeder populations induced a flux 3 to 4 times higher than that of passive sedimenting flux of particles.

In the Bay of Brest (West Brittany, France), although nutrient concentration and phytoplankton production are very high (Tréguer et al. 1985, Quéguiner et al. 1986), the environment does not exhibit symptoms of eutrophication. In fact phytoplankton biomass remains low in summer and fall (Quéguiner 1982) and the benthic macrofauna assemblages, apart from those of 
the harbour area, do not show signs of degradation due to organic enrichment (Hily 1983, 1984). Dense populations of suspension-feeding invertebrates proliferate on the sediment surface (Hily 1989), so the question was to what extent these suspension feeders participate by their filtration activity in the control of water quality and the maintenance of equilibrated conditions in the Bay ecosystem.

The purpose of this paper is to describe the favourable environmental conditions which may facilitate the proliferation of suspension-feeder populations, and to investigate whether the filtration capacity of these populations influences phytoplankton biomass and seston dynamics.

\section{MATERIALS AND METHODS}

Study site. Hydrology: The Bay of Brest $\left(48^{\circ} 16^{\prime} 50^{\prime \prime}\right.$ to $48^{\circ} 24^{\prime} 00^{\prime \prime} \mathrm{N}_{;} 04^{\circ} 15^{\prime} 00^{\prime \prime}$ to $04^{\circ} 33^{\prime} 30^{\circ} \mathrm{W}$ ) is a marine basin (mean salinity 32 to $33 \%$ ) which receives freshwater from 2 main rivers: the Aulne and the Elorn. The annual mean flow of these rivers combined is $37.95 \mathrm{~m}^{3}$ $\mathrm{s}^{-1}$. Exchanges between the Bay and ocean waters are limited by a narrow channel of $1.8 \mathrm{~km}$ width. The volume introduced into the bay from the external ocean water during every tidal cycle is comparable to the total annual freshwater volume discharged by the 2 rivers $\left(1.2 \times 10^{9} \mathrm{~m}^{3}\right)$. The main hydrodynamic feature is the strong tidal currents favouring vertical exchange and estuary/ocean water mixing.

Nutrient cycle and primary production: Brest, with its 250000 inhabitants on the north coast of the Bay, and the intensive agricultural activity in the drainage basin $\left(>1900 \mathrm{~km}^{2}\right)$ of the rivers, are sources of a heavy discharge of enriched organic effluents and levels of nutrients which are among the highest of comparable north European ecosystems: DIN (dissolved inorganic nitrogen) reaches $470 \mathrm{mM}$ in winter in the Aulne estuary, and in summer the lower levels of DIN in effluent freshwater $(90 \mathrm{mM})$ are balanced by high nutrient recycling from the soft sediments (Tréguer \& Quéguiner 1989). These conditions allow high annual primary production ( $220 \mathrm{~g} \mathrm{C} \mathrm{m}^{-2} \mathrm{yr}^{-1}$; Quéguiner 1982) characterized by successive blooms throughout the year, even in winter (100 to $200 \mathrm{mg} \mathrm{C} \mathrm{m}^{-2} \mathrm{~d}^{-1}$; Quéguiner 1982). Phytoplankton biomass is usually comparatively low: 1 to $1.5 \mathrm{mg} \mathrm{m}^{-2}$ chlorophyll a (except for spring blooms), which suggests a quick export from the pelagic system either to the open sea or to primary consumers (grazing by the zooplankton and the zoobenthos at the primary production site).

Sampling. In order to address the first question, concerning the proliferation of suspension feeders in the Bay, it was important to know the substratum condi- tions, which determine the dominance of infauna, epifauna or a mixed infauna/epifauna assemblage. Epifauna require either a compact sediment surface or hard supports such as shells, gravel or rocks. Infauna require soft sediments with the sediment surface free of hard fractions.

An underwater video television camera (Osprey S.I.T.) was used to observe and quantify the number of supports (shelly substrata of sessile species) on the sediment surface and to estimate the densities of epimacrofauna. Depending on the aims of the sampling, this camera was fixed to a dredge (Aquareve system; Thouzeau \& Hily 1986), to a benthic sledge (Laban et al. 1963), or handled by a SCUBA diver. Sampling by diving was also used to quantify densities and biomass of small species of epifauna and shelly substrata (1/4 $\mathrm{m}^{2}$ quadrat). Smith Macintyre $\left(1 / 10 \mathrm{~m}^{2}\right.$ samples) and Hamon grabs (1/4 $\mathrm{m}^{2}$ samples) were used to quantify the endofauna and analyse sediment.

Statistical methods. To represent the Ophiothrix fragilis distribution in the central bay, the geostatistical method of 'kriging' (Delfiner \& Delhomme 1973, Faucher 1986) was applied. This method determines interpolated values of densities on a regular mesh grid and allows optimal representation of lines of equal densities.

Densities and biomass. Densities are given in number of individuals $\mathrm{m}^{-2}$. All biomass values are given in $\mathrm{g}$ organic dry weight (ODW) $\mathrm{m}^{-2}$.

Filtration. To determine if suspension feeders controlled seston quality and quantity, it was necessary to estimate the filtered volume, not only per $\mathrm{m}^{2}$ but also integrating the whole bay surface. It is difficult to estimate with precision the in situ volume filtered by the suspension-feeding community of a given area for 3 reasons:

(1) Filtration rates of many species (like Balanus, Ophiothrix and Ficulina spp. locally dominant in the studied area) have never been measured.

(2) Filtration rates of some species (ascidians and bivalves), which have been calculated, are generally derived from in vitro experiments. Several problems may hinder a good comparative review of the literature data. The measured parameters and the understanding of the terminology can be different from one experiment to another. Generally, filtration rates are measured as the mean clearance rate of $100 \%$ efficiently retained particles, but the pumping rate, which is the volume passing through the animal's body, has been also measured as the filtration rate. Most data concern a major taxonomic group: molluscs and ascidians. Bayne (1976), Winter (1978) and Bayne \& Newell (1983) have given good reviews of filtration rates. Many bivalves have been studied: e.g. Cerastoderma edule: $7.91 \mathrm{~h}^{-1} \mathrm{~g}^{-1}$; Mytilus edulis Linnaeus: $2.81 \mathrm{~h}^{-1} \mathrm{~g}^{-1}$ 
(from Smaal et al. 1986). Endofaunal bivalves like Spisula solidissima Dillwyn have filtration rates ca 11 $\mathrm{h}^{-1} \mathrm{~g}^{-1}$; the value lies between $2 \mathrm{l} \mathrm{h}^{-1} \mathrm{~g}^{-1}$ (Crassostrea virginica Omelin) and $81 \mathrm{~h}^{-1} \mathrm{~g}^{-1}$ (Argopecten irradians Linnaeus) for epifaunal bivalves (Riisgård 1988a). Møhlenberg \& Riisgård (1979) calculated filtration rates from 4 to $81 \mathrm{~h}^{-1} \mathrm{~g}^{-1}$ for Cardium echinatum Linnaeus, $M$. edulis and Modiolus modiolus Linnaeus, and probably more than $10 \mathrm{l} \mathrm{h}^{-1} \mathrm{~g}^{-1}$ for Pecten furtivus Muller and $P$. opercularis. Filtration rate of $M$. edulis was estimated by Widdows et al. (1979) at $2.21 \mathrm{~h}^{-1} \mathrm{~g}^{-1}$. In ascidians, Fiala-Medioni (1973) calculated rates for Phallusia mammillata of $4.381 \mathrm{~h}^{-1} \mathrm{~g}^{-1}$, then estimated (1974) rates of 4 other ascidians to range between 2.4 and $6.9 \mathrm{l} \mathrm{h}^{-1} \mathrm{~g}^{-1}$. Styela clava Herdman filtration rates were $71 \mathrm{~h}^{-1} \mathrm{~g}^{-1}$ (Riisgård 1988b). Ascidiella aspersa and Ciona intestinalis Linnaeus rates were respectively 0.43 and $0.29 \mathrm{ml} \mathrm{s}^{-1}$ for an average sized individual of $0.154 \mathrm{~g}$ (soft tissue dry wt) (Randlov \& Riisgård 1979). Experimental methods were also extremely variable and consequently results are difficult to interpret, because of the difference in the seston quality used, the temperature, or the variable disturbance caused by the experiments. We agree with Møhlenberg \& Riisgård (1979) who considered that the literature values are probably very underestimated because of this disturbance and estimated the filtration as a power function of the body weight. Cloern (1982) used their results to calculate community filtration rate in south San Francisco Bay. Today, the most reliable in situ filtration rate estimate seems to be that obtained under semi in situ conditions as in Smaal et al. (1986); these authors calculated the clearance rate derived from the amount of seston filtered in a system of flow-through raceways with semi-natural steady state conditions under ambient conditions where natural seawater and seston as food were used. Clearance rate varied from 31.3 to $69 \mathrm{l} \mathrm{g}^{-1}$ AFDW d ${ }^{-1}$ in $M$. edulis.

(3) The filtration rate of a species is variable due to environmental factors such as temperature and seston quality and quantity, and individual weight. Young individuals have a higher filtration rate than the older individuals (Fiala-Medioni 1978, Møhlenberg \& Riisgård 1979), therefore rates can vary by as much as $50 \%$ within the same species (Desloup-Paoli \& Heral 1984).

From all these diversified values and the high variability of filtration under in situ conditions, the filtration rate, F, of the main species was estimated as a function of mean individual body weight (W, g dry wt)

$$
\mathrm{F}\left(1 \text { ind. } .^{-1} \mathrm{~h}^{-1}\right)=6 \mathrm{~W}^{0.7}
$$

which represents the mean filtration rate of suspension-feeding bivalves measured by Møhlenberg \& Riisgård (1979) and Riisgård (1988a).

\section{RESULTS}

\section{Habitat}

Characteristics of the 3 principal habitats are summarized in Table 1.

On the 'muddy banks' (Fig. 1) the Lithothamnium coralloides beds which covered the mud surface (silt fraction 30 to $80 \%$ ) on 3000 ha constituted a favourable structure for the settlement of many epifaunal species, especially bivalves whose juveniles use the adult shells (dead or active) as a support. Chlamys varia Linnaeus was the dominant bivalve in these sediments which were also the habitat of Ostrea edulis Linnaeus, Anomia ephippium Linnaeus and Modiolus barbatus Linnaeus. The ascidians Phallusia mammillata Cuvier, Ascidia mentula Muller, Ascidiella aspersa Muller, and the large free-living sponge Ficulina ficus Olivi, were also very common. The distribution of sessile epifauna species is dependent on the density of shells, cobbles, etc. lying on the sediment floor. The density of these supports $(\mathrm{X})$ was estimated at $60.3 \leq \mathrm{X} \leq 164.4 \mathrm{~m}^{-2}, \overline{\mathrm{X}}$ $=102.5 \mathrm{~m}^{-2}, \mathrm{SD}=70.05$. When the sediment surface was free of living Lithothamnium, the suspensionfeeder epifauna dominated with large bivalve species like Lutraria lutraria Linnaeus, Venerupis pullastra Montagu and Venus verrucosa Linnaeus.

In the transition zone of 'slopes and channels', the only abundant supports were the shells of Crepidula fornicata which are particularly suitable supports for its own juveniles, and also for Ophiothrix fragilis, Chlamys opercularis and C. varia.

In the 'central bay', the sediment surface was covered by flat gravels and stones on a coarse calcareous sand substrate which constituted optimal conditions for Ophiothrix fragilis Albigaard, Ophiocomina nigra Albigaard and Chlamys opercularis Linnaeus populations. Good ecological conditions also existed for Pecten maximus Linnaeus. Glycymeris glycymeris Linnaeus was the dominant endofaunal species in the coarse sand.

\section{Densities, biomass and trophic structure}

On the muddy shallow-water banks (Fig. 2), the epifauna with mixed Lithothamnium beds was dominated by suspension feeders: in numbers the small cirriped Balanus crenatus Bruguière was largely dominant, but in biomass it was the sponge Ficulina ficus which was dominant. Total suspension-feeder biomass was about $80 \mathrm{~g} \mathrm{~m}^{-2}$. There were 27 suspension-feeding species represented in the 6 major taxonomic groups. The associate endofauna of thes sediment was a Venus verrucosa community in which bio- 
Table 1. Habitats of the suspension feeders: general description of the sediment surface on the 3 main ecological units of the Bay of Brest; (minimum) mean (maximum)

\begin{tabular}{|c|c|c|c|c|c|c|c|c|c|}
\hline & \multicolumn{3}{|c|}{ Muddy banks } & \multicolumn{3}{|c|}{ Slopes and channels } & \multicolumn{3}{|c|}{ Central bay } \\
\hline Surface area (ha) & \multicolumn{3}{|c|}{5349} & \multicolumn{3}{|c|}{2515} & \multicolumn{3}{|c|}{2417} \\
\hline Depth (m) & (0) & 5 & (10) & (10) & 15 & (30) & (20) & 35 & $(40)$ \\
\hline Sediment & (Mud) & $\begin{array}{l}\text { Sandy } \\
\text { mud }\end{array}$ & $\begin{array}{l}\text { (Muddy } \\
\text { sand) }\end{array}$ & $\begin{array}{l}\text { (Sandy } \\
\text { mud) }\end{array}$ & $\begin{array}{l}\text { Fine } \\
\text { sand }\end{array}$ & $\begin{array}{c}\text { (Hetero- } \\
\text { geneous } \\
\text { sand) }\end{array}$ & $\begin{array}{l}\text { (Coarse } \\
\text { sand) }\end{array}$ & Gravel & (Stones) \\
\hline Shells $(\%)^{\mathrm{a}}$ & (10) & 30 & (60) & (0) & 10 & (20) & (0) & 50 & (100) \\
\hline Mud fraction $(\%)^{a}$ & (30) & 80 & (100) & (10) & 30 & (30) & (0) & 5 & (30) \\
\hline Stones and gravel $(\%)^{a}$ & (0) & 2 & (10) & (0) & 5 & (10) & (10) & 50 & (100) \\
\hline Macroalgae $^{\mathrm{b}}(\%)^{\mathrm{a}}$ & (10) & 40 & (100) & (1) & 2 & (5) & & 0 & \\
\hline $\begin{array}{l}\text { Macroalgae thickness } \\
(\mathrm{cm})\end{array}$ & (10) & 15 & (20) & (1) & 2 & (5) & & 0 & \\
\hline $\begin{array}{l}\text { Living Lithothamnium } \\
\text { banks (\%) }\end{array}$ & (10) & 50 & $(100)$ & (0) & 1 & (10) & & 0 & \\
\hline $\begin{array}{l}\text { Dead Lithothamnium } \\
(\%)^{\mathrm{a}}\end{array}$ & (10) & (30) & (60) & (0) & 10 & (20) & (0) & 5 & (10) \\
\hline Crepidula fornica (\%) & (0) & (10) & (60) & (0) & 50 & 100 & & 0 & \\
\hline
\end{tabular}

mass did not exceed $12 \mathrm{~g} \mathrm{~m}^{-2}$. Where the sediment surface was free of Lithothamnion and large supports, this community reached high biomass $\left(40\right.$ to $70 \mathrm{~g} \mathrm{~m}^{-2}$ ) with proliferation of Lutraria lutraria, Venerupis pullastra and Venus verrucosa. In the vicinity of the harbour, polluted conditions modify the structure of the benthic community (Hily 1984). However the sediment was colonized in high numbers (100 to 1000 ind. $\mathrm{m}^{-2}$ ) by opportunistic species such as tube-dwelling tentaculate polychaetes Polydora flava Clarapede, $P$. antennata Clarapede and Spio filicornis Müller which act as suspension feeders instead of deposit feeders, feeding on water-borne particles, and actively enhance particle removal from the water column (Frithsen \& Doering 1986).

In the slopes and channels, heavy dominance by one

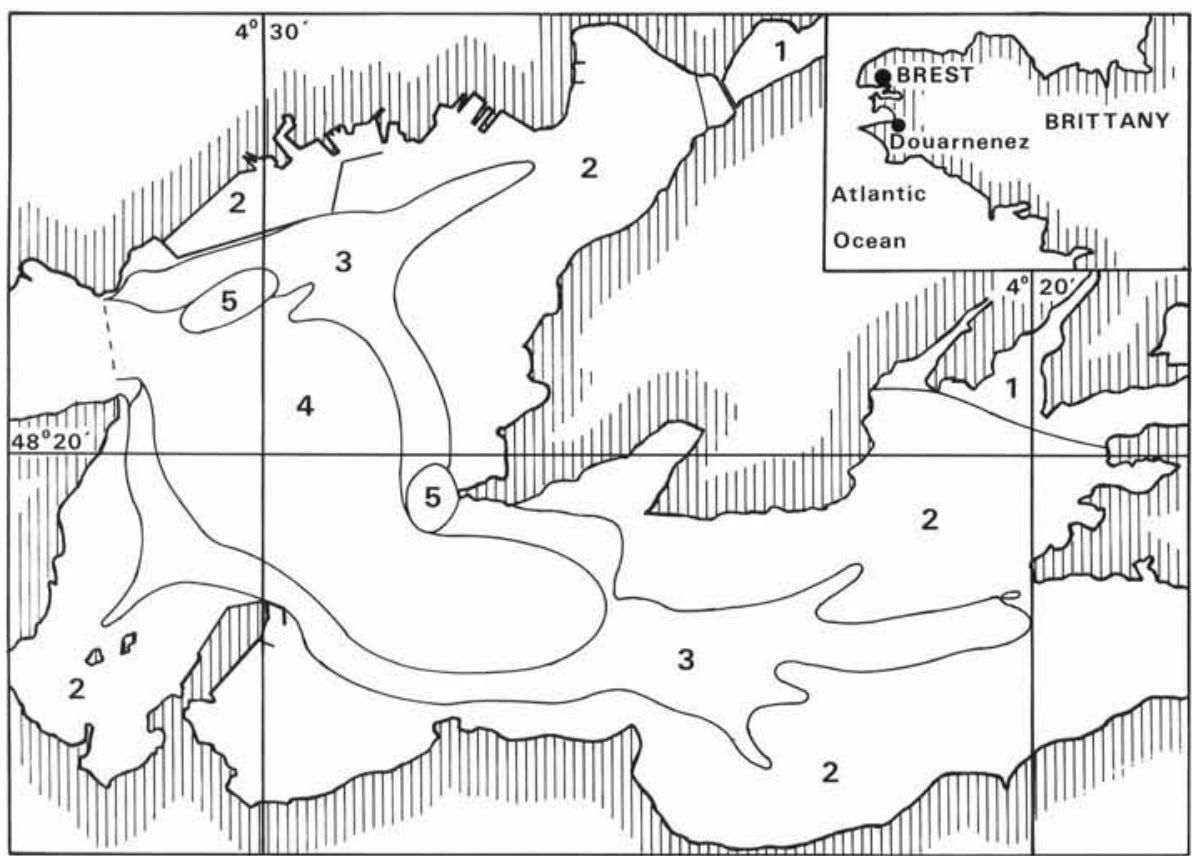

Fig. 1. Major ecological units of the Bay of Brest. (1) Estuarine area (intertidal); (2) 'muddy banks' with Lithothamnium coralloides beds $(0$ to $10 \mathrm{~m}$ ); (3) 'slopes and channels' transitional area with Crepidula fornicata beds (10 to $20 \mathrm{~m})$; (4) 'central bay' coarse sediments with Ophiothrix fragilis beds $(20$ to $40 \mathrm{~m}) ;(5)$ rock 


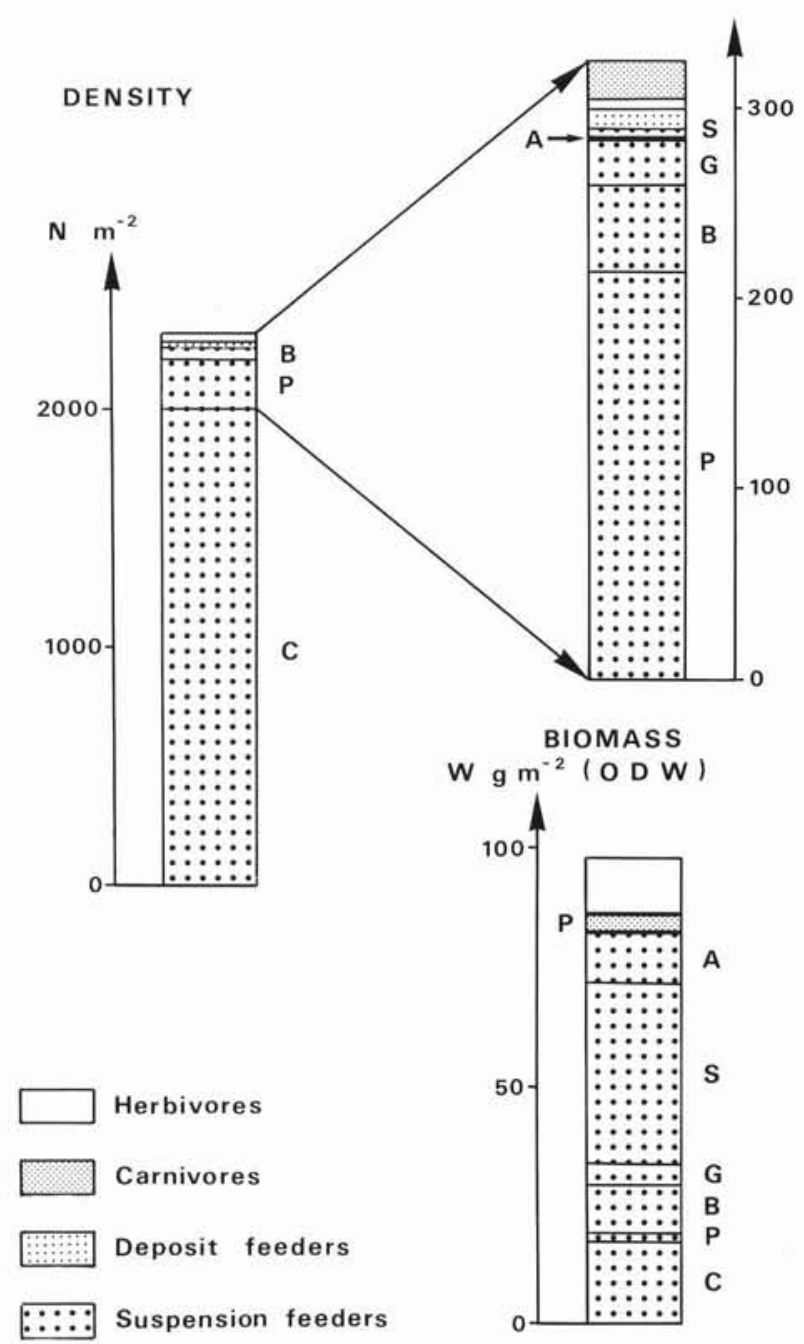

Fig. 2. Trophic structure of the epibenthic community of a Lithothamnium muddy bank bed. Density: number of individuals $\mathrm{m}^{-2}$; biomass: organic dry weight $\mathrm{m}^{-2}$. Data are mean values of 4 sampling series (winter, spring, summer and fall) from $6 \times 1 \mathrm{~m}^{2}$ (SCUBA sampling). C: Crustaceans; P: polychaetes; B: bivalves; G: gastropods; S: sponges; A: ascidians

species was more accentuated. Crepidula fornicata represented more than $80 \%$ in terms of biomass. This species, which can totally colonize the sediment surface, commonly reached $60 \mathrm{~g} \mathrm{~m}^{-2}(12 \mathrm{~kg}$ total wet weight $\mathrm{m}^{-2}$ ) at a coverage of $50 \%$ (ca 200 ind. $\mathrm{m}^{-2}$ ).

In the central bay, the suspension-feeding epifauna dominated the trophic structure in term of densities (Fig. 3) and biomass. Ophiothrix fragilis comprised most of the 20 to $50 \mathrm{~g} \mathrm{~m}^{-2}$ biomass. Chlamys opercularis, which is an exploited species, was the second most abundant ( 1 to 2 ind. $\mathrm{m}^{-2}$ ). The endofaunal bivalve Glycymeris glycymeris was well distributed over the whole area ( 20 to 30 ind. $\mathrm{m}^{-2}, 40$ to $60 \mathrm{~g} \mathrm{~m}^{-2}$ ) and commonly reached $200 \mathrm{~g} \mathrm{~m}^{-2}$ in dense monocohort populations.

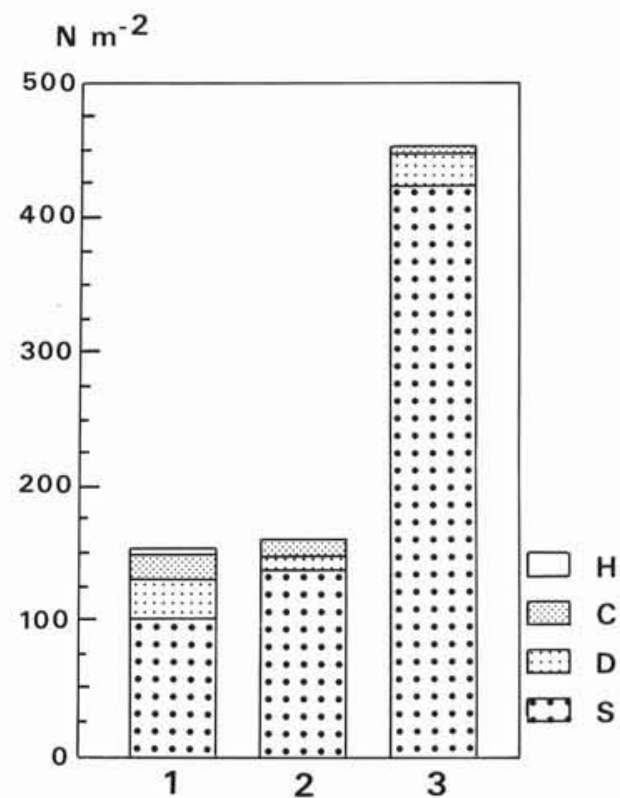

Fig. 3. Trophic structure of the epifauna community of the 'central bay'. Data are mean values of 12 samples of $1 \mathrm{~m}^{2}$ taken in winter with the Aquareve system (Thouzeau \& Hily 1986). Densities (number of individuals $\left.\mathrm{m}^{-2}\right)$ at 3 stations $(1,2$, 3) mainly differentiated by the number of Ophiothrix fragilis. $\mathrm{H}$ : herbivores; C: carnivores and predators; D: deposit feeders; S: suspension feeders

\section{Filtration capacities}

Within the benthic comunities, 11 suspension-feeding species were particularly abundant. We calculated the mean abundance and organic dry weight of these species from quantitative samples collected at sites in the 3 main habitats. Filtration rate of each species was estimated and multiplied by mean population density to give population filtration rate in each area. These were summed to estimate total filtration rate $(\mathrm{F})$ in each community $\left(\mathrm{m}^{3} \mathrm{~m}^{-2} \mathrm{~h}^{-1}\right.$ ) (Table 2 ). We also considered the daily pumping rhythm of suspension-feeding invertebrates. In situ experiments in the Bay of Brest (continuous observation for $24 \mathrm{~h}$ with underwater video camera on Chlamys varia and Phallusia mammillata populations) showed that these 2 species have an $80 \%$ pumping activity for 2 consecutive tidal cycles; this is in agreement with literature values (Fiala-Medioni 1978), so we have retained this rate to estimate the daily filtered volume per $\mathrm{m}^{2}$. The 11 species alone potentially filtered $7.55 \mathrm{~m}^{3} \mathrm{~m}^{-2} \mathrm{~d}^{-1}$ in muddy bank sites, $6.39 \mathrm{~m}^{3}$ $\mathrm{m}^{-2} \mathrm{~d}^{-1}$ in slopes and channel sites, and $6.36 \mathrm{~m}^{3} \mathrm{~m}^{-2}$ $\mathrm{d}^{-1}$ in central bay sites. Since the mean depths in these areas are respectively 5,15 and $35 \mathrm{~m}$, suspension feeders could filter a volume equivalent to $1.5,0.42$, and 0.18 times the water column volume daily in the sampled areas. 


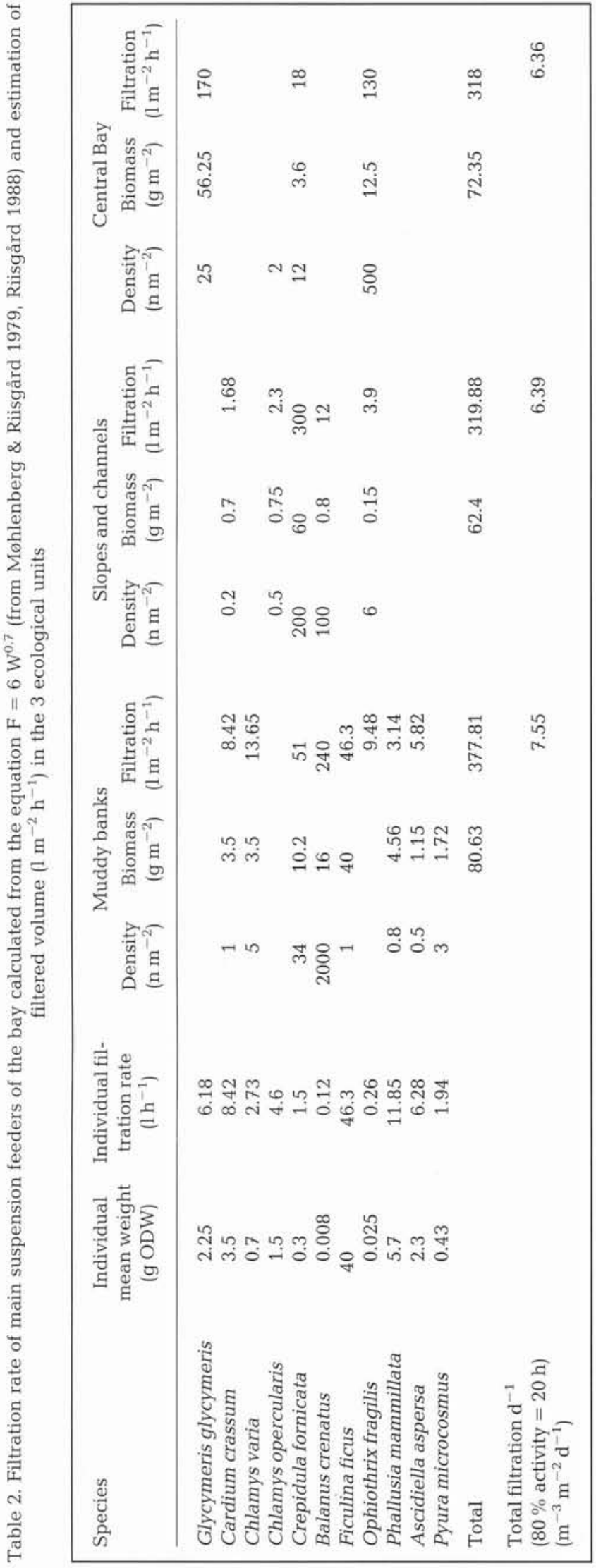

\section{DISCUSSION}

\section{Habitat and epifauna}

In a recent study, Hily \& Le Foll (1990) demonstrated that the distribution of large biotic supports $(\varnothing>2 \mathrm{~cm})$ was governed by 2 types of factors: hydrodynamics (tidal currents and waves) and fisheries activities, i.e. the dredging of the pectinid Chlamys varia which not only extracts the shellfish but also all supports lying on the substratum. These physical disturbances explain the high variability of the observed densities of supports. In the whole marine area of the bay, mainly in soft-bottom sediments, possibilities of settlement are numerous and diversified for epifauna. Such a situation is rare. This diversity of habitat explains the high specific diversity of the suspension feeders. Shells of dead individuals are used as support by living animals, which enable the assemblage of sessile species to persist on a soft bottom sediment. This diversity of the sediment surface structure explains the high density and biomass values: on some types of substrate 1 or 2 species are under optimal ecological conditions and can proliferate (Ophiothrix and Crepidula beds) and on other types a structured diversified assemblage of suspension-feeder species also reach high biomass (Lithothamnium banks).

\section{Filtration capacities}

The calculated filtration rate of suspension feeders was based exclusively on bivalve molluscs which are active pumping filterers. The relation between individual mean weight and filtration rate can easily be applied for ascidians and gastropods (see literature values in 'Material and methods') which are equally active suspension feeders. However, sponges, crustaceans and ophiurids, which can represent locally more than $50 \%$ of the suspension-feeding biomass, are semiactive or passive filter feeders. These are considered to have lower filtration rates than active pumping species because of their simplified anatomic system of capture, selection and digestion of suspended particules. This would lead to calculated rates of filtration being overestimates if data are derived from bivalves and ascidians. On the other hand, passive suspension feeders are generally localized to areas in strong current conditions and the flux of accessible particles for passive suspension feeders could be equivalent to those of active pumping species; consequently their filtration rates should not be far from those of ascidians and molluscs. We thus concluded that for a first estimate of the global importance of filter feedig activity in the Bay of Brest such an approximation seemed acceptable. 
Using this hypothesis the total volume filtered daily in the whole bay may be estimated: from the surface area and mean depth of each ecological unit (Table 1) the total water volume of the sampling area is $14.80 \times 10^{8}$ $\mathrm{m}^{3}$ (the total volume of the bay ranges between $16.5 \times$ $10^{8} \mathrm{~m}^{3}$ at low tide and $29.4 \times 10^{8} \mathrm{~m}^{3}$ at high tide). From Table 2 the total volume filtered daily should be $7.18 \times$ $10^{8} \mathrm{~m}^{3}$, which represents a volume equivalent to $31 \%$ of the total volume of the bay.

However, because of the high variability of the distribution of densities and biomass in each area, it is difficult to extrapolate directly the results of the sampled stations to an estimate of the total daily filtered volume in the whole bay. Densities and biomass are linked by the population dynamic patterns of the dominant suspension-feeding species (Glycymeris glycymeris, Ficulina ficus, Ophiothrix fragilis, Crepidula fornicata, Lutraria lutraria). These species show unpredictably dense - frequently monocohort - populations superimposed on the base-line of the community but can also have very low densities in the same ecological unit. Consequently mean realistic densities and biomass of such species are not easily predictable on a scale of more than 1000 ha and are probably lower than those observed at the sampled stations. However, even on the hypothesis that mean densities and filtration rate are $50 \%$ overestimated, the volume of the Bay of Brest should be filtered in 4 to $6 \mathrm{~d}$ which is comparable with the situation of Lake Grevelingen (Netherlands; Verhagen 1983). This rough theoretical value underlines that the daily filtered volume is greater than the water mass volumes exchanged daily in the bay: indeed only $6 \%$ of the total volume of the bay is renewed every day by tidal exchanges because a large part of the water leaving the bay during the ebb tide returns during the flood (Delmas 1981). The theoretical daily filtered volume is higher than the total annual freshwater discharged into the bay by rivers. Thus in terms of global estimation of flux in the ecosystem, the role of filtration by the benthos cannot be neglected, especially during neap tide periods where the impact of filtration is enhanced in the Bay of Brest, due to low vertical mixing by tidal currents, and low daily volumes of water masses exchanged with the open sea. In this case eutrophication and blooming can easily occur.

\section{Availability of phytoplankton resource to benthos}

Is the phytoplankton biomass which is produced just near the water surface easily accessible to the benthos? This is an essential question since the impact of grazing is very different if it occurs on dead diatoms and microalgae sedimenting from the upper production layer, or if it occurs on living phytoplankton still able to reproduce and grow. Effectively, when suspension feeders exploit a sedimenting dead phytoplankton source they cannot actively control the primary production.

Analysis of the pelagic system functioning of the Bay of Brest reveals many features which may favour rapid access of the benthos to living phytoplankton populations:

- The mean depth of the bay is $10 \mathrm{~m}$; there is thus a short vertical distance between the production and the consumption layers.

- Tidal currents are ceaseless and induce effective vertical mixing, thus preventing stratification. As a result, chlorophyll a biomass is found to be uniform in the water column (Quéguiner 1982). The bottom infaunal activity may explain the difference observed by Quéguiner (1982) between the high phytoplankton production and the low phytoplankton biomass in summer and fall. Such observations have also been made by De Vries \& Hopstaken (1984) in Lake Grevelingen in which filtering by bottom fauna is an important mortality factor for phytoplankton.

- Because of the long residence time of the water in the bay ( 15 to $30 \mathrm{~d}$ ) (Delmas 1981), phytoplankton blooms can develop easily depending on nutrients in the bay; they can then be grazed on site by the benthos. Cloern (1982), in agreement with Officer et al. (1982), concluded that benthic filter feeders are important as a natural control of eutrophication by reducing phytoplankton biomass, especially in shallow waters with long residence time.

- Trophic competition with zooplankton can be neglected because of the long latency period ( $7 \mathrm{~d}$ according to Quéguiner 1982) between phyto- and zooplankton biomass maxima. Moreover high zooplankton biomass occurs only during the spring period $\left(120 \mathrm{mg} \mathrm{m}^{-3}\right.$; Quéguiner 1982) when phytoplankton production is in excess.

- Phytoplankton biomass is not the only resource of filter feeders. In the Bay of Brest, macrophytes develop annually on the shallow water muddy banks and their biomass reaches $9 \mathrm{~g} \mathrm{C} \mathrm{m}^{-2}$ (Potin \& Hily unpubl.). Macrophyte detritus is available to suspension feeders by hydrodynamic resuspension. As was shown by Wulff \& Field (1983), a community in which macroalgae represent $63 \%$ of the primary production is largely dominated in biomass by suspension feeders because they filter macrophyte detritus kept in suspension by wave action. For the period of low primary production fall and winter - macrophyte detritus is very important in the Bay of Brest and suspension feeders should be able to live from the detritus kept in suspension by frequent winter storms.

- While substratum quality is the determining factor in settlement of suspension-feeding species, the 

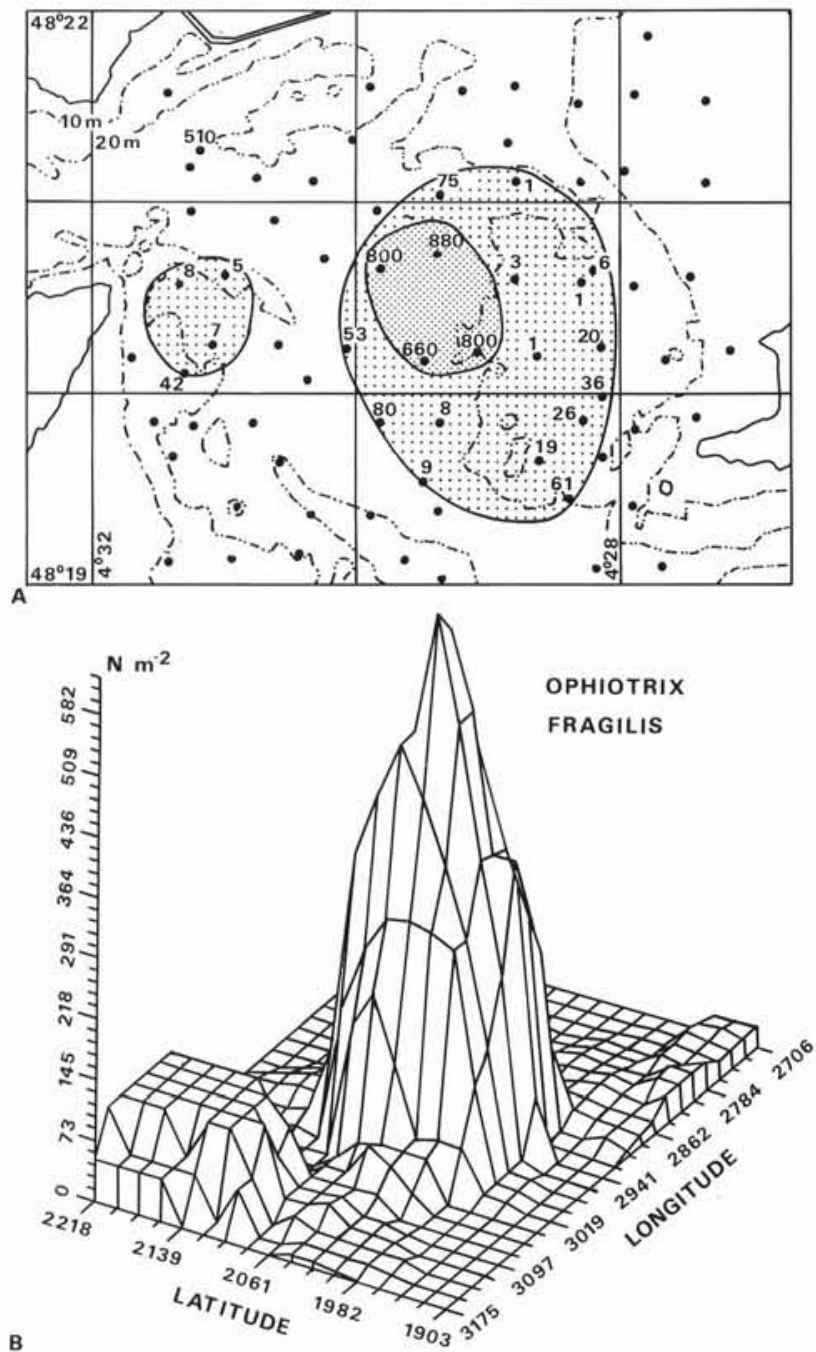

Fig. 4. Ophiothrix fragilis. Densities (May 1986). (A) Data and manual interpretation. (B) Automatic linear interpolation by the geostatistical method of kriging. Densities: number of individuals $\mathrm{m}^{-2}$

characteristics of tidal currents determine nutrition and growth. Dense populations were always observed in areas where the species is adapted to exploit the pelagic system in relation to the local feature of tidal currents: on muddy banks the main species are suspension feeders which actively pump the water, such as ascidians, sponges and bivalves. In these environments the mean current speed remains under 1 knot. In the central part of the bay Ophiothrix fragilis are passive suspension feeders which catch seston with their armspines (Roushdy \& Hansen 1960, Warner 1971). The local distribution of this population can be superimposed upon that of the tidal currents: indeed from the numerical model of Salomon (1980), the tidal currents of the central bay establish a cyclonic vortex centred on the area of the most dense Ophiothrix beds. Residual currents also show this pattern (Salomon 1980). The distribution of Ophiothrix in terms of density is a succession of concentric rings in which the maximum corresponds to the central part of the vortex (Fig. 4A). The use of the geostatistical method of kriging to study the spatial distribution of Ophiothrix (Fig. 4B) is particularly demonstrative of the ringed cone distribution. It appears that this distribution is temporally stable: the 2 sampling surveys in 1985 and 1989 showed the same general features of this population. This feature of the currents presumably both induces favourable conditions for accessibility of the nutritive part of the seston to the Ophiothrix population, and enhances the settlement probability of the pelagic larvae of this species.

It is well known that the global nutrient discharge by rivers has considerably increased during recent years (especially DIN rates due to agricultural residues). The consequences of such an increase were not quantified but probably stimulated phytoplankton production. At the same time the biomass filter-feeding benthos increased: this is particularly evident with the rapid extension of the Crepidula fornicata population, which was rarely observed in the 1950's and which now constitutes important stocks of thousands of tons (Coum 1979). It may be hypothesized that this suspension-feeding species has opportunistically increased in biomass partly in response to higher phytoplankton production which should act as a mechanism of regulation preventing eutrophication. Despite the short-term unpredictable spatial/temporal distribution of plankton, long-term development probably adjusts the total biomass of suspension feeders to the mean primary production.

\section{CONCLUSIONS}

The mechanisms implied in the control of the pelagic system by the benthos are numerous and complex. To quantify all levels of this subsystem, more specific studies must be undertaken. Nonetheless the results reported here indicate that the Bay of Brest ecosystem has specific features which allow a high density of benthic suspension feeders which can control the water quality by grazing on the phytoplankton biomass at least during short periods particularly in summer and winter. This phenomenon is possible because the benthic community is capable of filtering the water of the bay with a time constant shorter than the hydrodynamic residence time and comparable with the time constant for plankton growth. However, as compared with south San Francisco bay (Cloern 1982) and other similar areas, the impact of suspension feeders is probably lower in the Bay of Brest because of its greater depths, its shorter residence time and its stronger tidal currents. Moreover, important blooms occur in spring 
and autumn in the Bay of Brest but not in south San Francisco bay. The Bay of Brest system is much more similar to the Oosterschelde (Smaal et al. 1986) where suspension feeders (mainly exploited Mytilus edulis and 'wild' cockles Cerastoderma edule) filter the total volume in 4 to $5 \mathrm{~d}$. Furthermore the primary production of the Oosterschelde is 160 to $300 \mathrm{~g} \mathrm{C} \mathrm{m}^{-2} \mathrm{yr}^{-1}$ which is comparable to that of the Bay of Brest. In such environments the effect of suspension feeders is not only a simple consumption of seston but also a stimulatory feed-back effect to water column producer by nutrient regeneration from the faeces and pseudofaeces as demonstrated by Doering et al. (1986). In the central bay, where currents prevent gravitational sedimentation, the capture of organic particles by suspension feeders reduces their export to the open sea, and allows organic enrichment by biodeposition which induces a diversified deposit feeder infauna, unusual in such coarse sands and gravels (Hily unpubl.).

Finally, the Bay of Brest is of interest in a general discussion on the role of benthic suspension feeders in pelagic/benthic interactions and particularly their role as a natural eutrophication control (Officer et al. 1982). The important features noted in this work are: (1) the greater importance of suspension-feeding epifauna compared to suspension-feeding endofauna; (2) the high diversity of biotopes and filter-feeding species along a natural succession from shallow waters loaded with nutrient discharges to deeper bottoms, corresponding to a progressive decreasing impact of the benthos on the pelagic system; (3) the importance of small organisms like Balanus and Ophiothrix spp.; (4) the high tidal current mixing which minimizes the effects of the relatively high average depth and allows the benthos to exploit the living phytoplankton populations; and finally (5) the possibility for these suspension-feeding species to feed on macroalga detritus during low phytoplankton biomass periods.

\section{LITERATURE CITED}

Bayne, B. L. (1976). Marine mussels: their ecology and physiology, Cambridge University Press, London

Bayne, B. L., Newell, R. C. (1983). Physiological energetics of marine molluscs. In: Saleuddin, A. S. N., Wilbur, K. M. (eds.) The Mollusca, Vol. 3, Part 1. Academic Press, New York, p. 407-515

Boynton, W. R., Kemp, W. M., Osbourne, C. G. (1980). Nutrients fluxes across the sediment-water interface in the turbid zone of a coastal plain estuary. In: Kennedy, V. S. (ed.) Estuarine perspectives. Academic Press, New York, p. 93-109

Cloern, J. E. (1982). Does the benthos control phytoplankton biomass in south San Francisco bay? Mar. Ecol. Prog. Ser. 9: 191-202

Coum, A. (1979). La population de crépidules (Crepidula fornicata) en Rade de Brest. Ecologie et dynamique. Thèse de 3ème Cycle, Univ. Bret. Occid. Brest

Dame, R., Zingmark, R., Stevenson, H., Nelson, D. (1980). Filter feeder coupling between the estuarine water column and benthic subsystems. In: Kennedy, V.S. (ed.) Estuarine perspectives. Academic Press, New York, p. 521-526

Delfiner, P., Delhomme, J. P. (1973). Optimum interpolation by kriging. Bull. Centre de Morphologie Math. Fontainebleau no. 343

Delmas, R. (1981). Etude de l'évolution saisonnière des sels nutritifs dans la rade de Brest en fonction des apports fluviaux et des échanges avec l'Iroise. Thèse de 3ème cycle, Univ. Sci. Brest

Desloup-Paoli, J. M., Heral, M. (1984). Transferts énergétiques entre l'huître Crassostrea gigas de un an et la nourriture potentielle disponible dans l'eau d'un bassin ostréicole. Naliothis 14: 79-90

Desloup-Paoli, J. M., Heral, M., Massé, N. (1983). Bilan énergétique d'une population naturelle de Crepidula fornicata dans le bassin de Marennes-Oléron. Bases biologiques de l'aquaculture, Montpellier, IFREMER, Actes de Colloques 1: 109-124

Doering, P. H., Oviatt, C. A., Kelly, J. R. (1986). The effects of the filter-feeding clam Mercenaria mercenaria on carbon cycling in experimental marine mesocosms. J. mar. Benthos 44: 839-861

Faucher, C. (1986). Ecologie dynamique d'une plage de sable fin (Saint Michel en Grève), après la pollution pétrolière de 'l'Amoco Cadiz'. Thèse Doc. 3ème Cycle, Univ. Bret. Occid. Brest

Fiala-Medioni, A. (1973). Ethologie alimentaire d'invertébrés benthiques filtreurs (Ascidies). I. Dispositif expérimental. Taux de filtration et de digestion chez Phallusia mammillata. Mar. Biol. 23: 137-145

Fiala-Medioni, A. (1978). Filter-feeding ethology of benthic invertebrates (ascidians). Influence of temperature on pumping, filtration and digestion rates and rhythms in Phallusia mammillata. Mar. Biol. 48: 251-259

Frithsen, J. B., Doering, P. H. (1986). Active enhancement of particle removal from the water column by tentaculate benthic polychaetes. Ophelia 25 (3): 169-182

Héral, M., Deslous-Paoli, J. M., Sornin, J. M. (1983). Transferts énergétiques entre l'huître Crassostrea gigas et la nourriture disponible dans un bassin ostréicole: premières approches. Oceanis 59: 169-194

Hily, C. (1983). Modifications de la structure écologique d'un peuplement de Melinna palmata (Annelide Polychète) soumis aux effluents urbains et industriels en Rade de Brest. Ann. Inst. Oceanogr., Paris: 59, 1: 37-56

Hily, C. (1984). Variabilité de la macrofaune benthique dans les milieux hypertrophiques de la Rade de Brest. Thèse de Doc. ès Sciences, Univ. Bret. Occid., Brest

Hily, C. (1989). La mégafaune benthique des fons meubles de la Rade de Brest: pré-échantillonnage par vidéo sousmarine. Cah. Biol. mar. 30: 433-454

Hily, C., Le Foll, D. (1990). Distribution des supports coquilliers sur les fonds meubles infralittoraux: rôle des perturbations physiques et conséquences sur l'abondance et la distribution d'une population de Chlamys varia. C. R. Acad. Sci. Paris, 311 ser. III: 187-192

Hobbie, J. E. (1976). Nutrients in estuaries. Oceanis 19: 41-47

Laban, A., Peres, J. M., Picart, J. (1963). La photographie sousmarine profonde et son explication scientifique. Bull. Inst. Oceanogr. 60: 1-32

Møhlenberg, F., Riisgård, H. U. (1979). Filtration rate, using a new indirect technique, in thirteen species of suspensionfeeding bivalves. Mar. Biol. 54: 143-147 
Officer, C. B., Smayda, J. H., Mann, R. (1982). Benthic filter feeding: a natural eutrophication control. Mar. Ecol. Prog. Ser. 9: 203-210

Quéguiner, B. (1982). Variations qualitatives et quantitatives du phytoplancton dans un système eutrophe fortement soumis aux effets des marées: la Rade de Brest. Thèse 3ème cycle. Univ. Bret. Occid. Brest

Quéguiner, B., Hafsaoui, M., Tréguer, P. (1986). Simultaneous uptake of ammonium and nitrate by phytoplankton in coastal ecosystems. Estuar. coast. Shelf Sci. 751-757

Randlov, A., Riisgård, H. U. (1979). Efficiency of particle retention and filtration rate in four species of ascidians. Mar. Ecol, Prog. Ser. 1: 55-59

Riisgård, H. U. (1988a). Efficiency of particle retention and filtration rate in 6 species of Northeast American bivalves. Mar. Ecol. Prog. Ser. 45: 217-223

Riisgård, H. U. (1988b). The ascidian pump: properties and energy cost. Mar. Ecol. Prog. Ser. 47: 129-134

Roushdy, H. M., Hansen, V. K. (1960). Ophiuroids feeding on phytoplankton. Nature, Lond. 5: 517-518

Salomon, J. C. (1980). Sur un procédé numérique d'exploitation de données courantométriques (rapp. Int. CNRS). In: S.A.U.M. (Shèma d'Amenagement et d'Utilisation de la Mer) de la Rade de Brest. Ministère de l'Environnement/ Ministère des Transports/D.D.E. Brest

Smaal, A. C., Verhagen, J. H. G., Coosen, J., Haas, H. A. (1986). Interaction between seston quantity and quality and benthic suspension feeders in the Oosterschelde, The Netherlands. Ophelia 26: 385-399

Smayda, T. J. (1976). Plankton processes in Midatlantic nearshore and shelf waters and energy related activities. In: Manowitz, B. (ed.) Effects of energy-related activities on the Atlantic continental shelf. Proc. of a conference at Brookhaven National Laboratory, p. 70-94

Sornin, J. M. (1981). Processus sédimentaires et biodéposition liés à différents modes de conchyliculture. Thèse de 3ème Cycle, Univ. Sci. Nantes

This article was submitted to the editor
Thouzeau, G., Hily, C. (1986), Aquareve: une technique nouvelle d'échantillonnage quantitatif de la macrofaune épibenthique des fonds meubles. Oceanologica Acta 9 (4): 509-513

Tréguer, P., Quéguiner, B. (1989). Seasonal variations in conservative and non-conservative mixing of nitrogen compounds in a west European macrotidal estuary. Oceanologica Acta 12 (4): $371-380$

Tréguer, P., Delmas, R.,Le Jehan, S. (1985). Conservativité et non conservativité de la distribution des matières nutritives et organiques, dissoutes et particulaires, en écosystèmes marin et estuarien macrotidal. Oceanis 11: $169-180$

Verhagen, J. H. G. (1983). A distribution and population model of the mussel Mytilus edulis in Lake Grevelingen. In: Lauenroth, W. K., Skogerboe, G. V., Flug, M. (eds.) Analysis of ecological systems: state-of-the-art in ecological modelling. Elsevier Scientific Publishing Company, Amsterdam, p. 373-383

Vries, I. De, Hopstaken, C.F. (1984). Nutrient cycling and ecosystem behaviour in a salt-water lake. Neth. J. Sea Res. 18: 221-245

Warner, G. F. (1971). On the ecology of a dense bed of the brittle-star Ophiothrix fragilis. J. mar. biol. Ass. U.K. 51: 267-282

Widdows, J., Fieth, P., Worrall, C. M. (1979). Relationships between seston, available food and feeding activity in the common mussel Mytilus edulis. Mar. Biol. 50: 195-207

Winter, J. (1978). A review of the knowledge of suspension feeding in lamellibranchiate bivalves, with special referencs to artificial aquaculture systems. Aquaculture 13: $1-33$

Wulff, F. V., Field, J. G. (1983). Importance of different trophic pathways in a nearshore benthic community under upwelling and downwelling conditions. Mar. Ecol. Prog. Ser. 12: $217-228$

Manuscript first received: March 2, 1990

Revised version accepted: September 26, 1990 